\title{
Андрій Вознесенський
}

\section{ОСТРОЗЬКА ТИПОГРАФІЯ І ВИДАННЯ ПОСЛАНЬ КОНСТАНТИНОПОЛЬСЬКОГО ПАТРІАРХА ЄРЕМIÏ II}

При вивченні діяльноті давніх типографій нерідко виникають питання, вирішення яких ускладнюється через відсутність або нестачу документальних свідчень про роботу друкарів. У таких випадках фундаментом для формування бодай якогось уявлення про предмет студій, як правило, стають видання, що побачили світ у цих типографіях.

Щоправда, і тут на дослідника чатують небезпеки. Часто замість того, аби зайнятися приборканням власної фантазії, він змушений вдаватися до перевірки залученого матеріалу, встановлювати правильність опису видань, їх атрибуції і датування. Іноді це призводить до несподіваних результатів, що ведуть до переосмислення того, як розвивалося книгодрукування в ту чи іншу епоху на тих чи інших землях. Саме з такою ситуацією можна зіштовхнутися, коли звернемося до видань острозької типографії 1580 -х років, які, відтак, заслуговують на спеціальну увагу.

Острозька типографія виникла в кінці 70-х років XVI ст. Ініціатором іiі створення став князь Василь-Костянтин Острозький, який запросив до своєї резиденції уже відомого за роботою в Москві, Заблудові і Львові друкаря Івана Федорова. Мета запрошення була цілком очевидною: Іван Федоров мав втілити у життя давнє бажання князя дати православним слов'янам друковану Біблію. Правда, підготовка видання затягнулася. За цей час Іван Федоров встиг випустити дві Абетки, причому одну греко-слов'янську (для потреб острозької школи), Новий Завіт з Псалтирем, оснащений (не виключено, 3 власної ініціативи) предметним покажчиком, а також «Хронологію» Андрія Римші (ймовірно, виконуючи замовлення автора). Врешті, в серпні 1581 p. те, чого жадав князь В.-К. Острозький, здійснилося: видання Біблії було здійснене. Після цього і аж до смерті друкаря наприкінці 1583 р. типографія не працювала: князь В.-К. Острозький більше не бачив у ній потреби, а Іван Федоров не мав коштів не тільки на продовження книгодрукування, а й на виплату доволі значних боргів, які накопичилися в нього до того моменту.

Тривалий час вважалося, що й після смерті Івана Федорова острозька типографія не припинила свого існування, тим більше, що в Острозі залишалися кваліфіковані кадри. Серед них називають, зокрема, Герасима 
Смотрицького, який раніше працював над виданням Острозької Біблії, а також Василя Суразького ${ }^{1}$. Зазвичай, Герасиму Смотрицькому приписують авторство «Ключа царства небесного», надрукованого разом 3 «Календарем римським новим», як вважають, в Острозі в 1587 році. Василя Суразького розглядають в якості якщо не автора, то видавця збірника «О єдиній істинній православній вірі», відомого також як «Книжиця в шести розділах». На думку багатьох дослідників, збірник побачив світ там само близько 1588 року. Крім того, острозькими прийнято вважати і дві брошури з посланнями константинопольського патріарха Сремії II, випущені начебто ще в першій половині 1580-х, а також Абетку, надруковану орієнтовно наприкінці цього ж десятиріччя. Всі перераховані видання, за винятком хіба що «Книжиці в шести розділах», є надзвичайно рідкісними; всі їх відомі екземпляри характеризуються відсутністю вихідних даних. Можливо, цим і пояснюється та впевненість, з якою в бібліографії виконувалися їх атрибуція і датування.

Сумніви в тому, що «Ключ царства небесного» був продуктом острозької типографії, а «Книжиця в шести розділах» з'явилася близько 1588 р., висловив лише Ігор Мицько. Автор підкріпив свою думку тим, що шрифт першого 3 названих друків зустрічається і у віленських виданнях 1580-х років, а аналіз типографічного матеріалу «Книжиці в шести розділах» примушує вважати іiї опублікованою лише через десятиліття. У підсумку І. Мицько прийшов до висновку, що між 1581 і 1594 р. друкарня в Острозі не працювала². На жаль, це важливе спостереження засновувалося на вивченні далеко не всіх «острозьких» видань 1580-х, до того ж воно не було належним чином акцентоване в дослідженні. Можливо, тому його спробувала врахувати тільки Віра Фрис, яка зробила поклик на монографію Ігоря Мицька, описуючи примірник «Ключа царства небесного» ${ }^{3}$. Вона ж передатувала 1598 роком «Книжицю в шести розділах» ${ }^{4}$ хоча в списку всіх острозьких друків, які В. Фрис перераховує в каталозі, зовсім нескладно знайти й обидва видання послань патріарха Єремії («Острог (?), після 1583»), i «Ключ царства небесного» («Острог, [1587]»), і Абетку («Острог, 80-і рр. XVI ст.») ${ }^{6}$. Водночас,

\footnotetext{
${ }^{1}$ Коляда Г.I., Ісаєвич Я.Д. Друкарська справа на західноукраїнських землях (XVIXVIII ст.) // Книга і друкарство на Україні. - Київ, [1965]. - С. 49; Исаевич Я.Д. Преемники первопечатника. - Москва, 1981. - С. 9.

${ }^{2}$ Мицько І.3. Острозька слов'яно-греко-латинська академія (1576-1636). - Київ, 1990. - С. 43.

${ }^{3}$ Каталог кириличних стародруків Львівської наукової бібліотеки ім. В Стефаника Національної академії наук України. - Львів, 1996. - Вип. 2: Видання друкарень Острога, Дермані, Стрятина, Крилоса, Угорець, Рохманова / Автор-уклад. В. Фрис. - С. 7.

${ }^{4}$ Там само. - C. 25.

${ }^{5}$ Раніше Віри Фрис сумніви щодо послань патріарха Єремії висловив Федір Максименко, щоправда, йому не сподобалося їх датування (див.: Максименко Ф.П. Кириличні стародруки українських друкарень, що зберігаються у львівських збірках (1574-1800). - Львів, 1975. № 187, 188).

${ }^{6}$ Там само. - С. 103.
} 
для інших спеціалістів міркування І. Мицька залишилося зовсім непоміченим $^{7}$, що, на нашу думку, і створює необхідність детальнішого вивчення згаданих видань.

Першими острозькими друками, що з'явилися по смерті Івана Федорова, традиційно вважають дві брошури 3 посланнями патріарха Єремії II (Іл. 1,2$)$, які тривалий час описувалися як одне видання. Про те, що це не одне, а таки два видання, хай навіть і без необхідних пояснень, першою заявила Тетяна Бикова ${ }^{8}$. Очевидно, вона помітила і особливе виділення набірним орнаментом першого аркуша в кожному з них, і відсутність у першій брошурі (при наявності в другій) пагінації, $\mathrm{i}$, врешті, те, що обидва послання складалися 3 двох зошитів, в одному з яких було чотири, а в іншому два аркуші (тобто вони були видруковані на аркуші і піваркуші паперу). У будь-якому разі, думка дослідниці була прихильно сприйнята бібліографами і з часом здобула загальне визнання9.

Зміст брошур доволі примітний - обидві включають тексти, створені 3 нагоди запровадження в Речі Посполитій григоріанського календаря (1582 р.), що призвело до розгубленості, а часом навіть хвилювання православного населення. Центральне місце у першій брошурі займає відповідь патріарха Єремії II на лист В.-К. Острозького, стурбованого цією ситуацією (разом з Єремією послання підписав александрійський патріарх Сильвестр). Окрім відповіді князю, у першій брошурі міститься ще три послання. Перше, до київського митрополита Онисифора, повідомляє про відправлення патріархом двох екзархів, які мали вислухати претензії православних до «латиномудрених», в супроводі Феодора «спудея». Далі йде послання самих екзархів (протосингела Никифора і архімандрита Діонісія) до єпископа Пінського і Турівського Кирила Терлецького. Перебуваючи в Яссах, вони повідомляли владику про те, що через навалу татар змушені затриматися в дорозі, і тому відряджають поперед себе Феодора «спудея», аби той виконав їхню місію. Ще одне послання Єремії ІІ, адресоване «всим православнымъ хрестияномъ страны северныя, наипаче же подвизающимся по благочестию гражаномъ Вилни града», є, судячи зі змісту, супровідним листом для Феодора «спудея».

\footnotetext{
${ }^{7}$ Це легко відстежити за згадками видань в бібліографії. Див., наприклад: Грииевская И.М. Книги кириллической печати XVI-XVII веков в фондах Нижегородской областной библиотеки: Каталог. - Нижний Новгород, 1992. - № 9; Лукьяненко В.И. Издания кириллической печати XV-XVI вв. (1491-1600): Каталог книг из собрания ГПБ. - Санкт-Петербург, 1993. № 88, 89, 97; Гусева А.А. Издания кирилловского шрифта второй половины XVI века: Сводный каталог / Под общ. ред. Л. И. Сазоновой. - Москва, 2003. - № 80, 93, 94, 104, 108.

${ }^{8}$ Каталог изданий Острожской типографии и трех передвижных типографий / Сост.: Т. А. Быкова. Л., 1972. № 5 и 6.

9 Запаско Я.П., Ісаєвич Я.Д. Пам'ятки книжкового мистецтва: Каталог стародруків виданих на Україні. - Львів, 1981. - Кн. 1: (1574-1700). - № 16 и 17; Лукьяненко В.И. Издания кириллической печати XV-XVI вв. - № 88, 89; Гусева А.А. Издания кирилловского шрифта второй половины XVI века. - № 93, 94.
} 


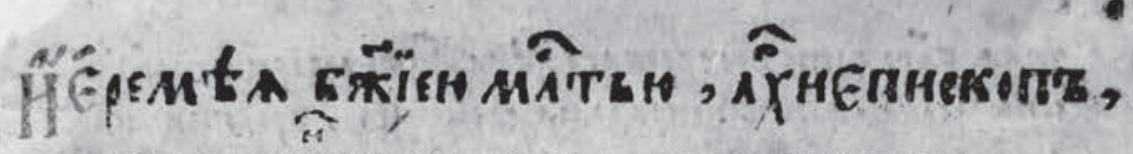

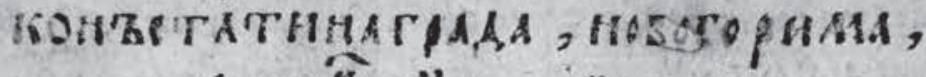

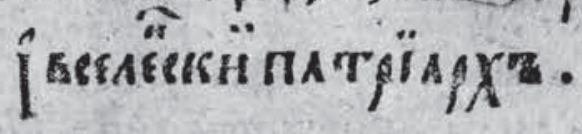

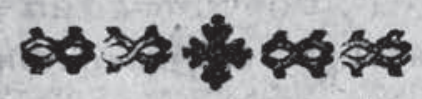

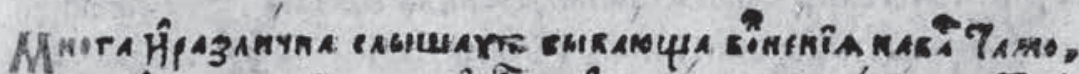

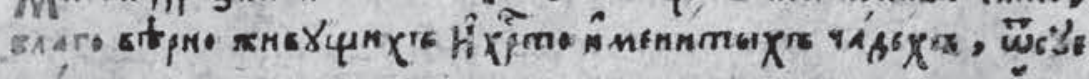

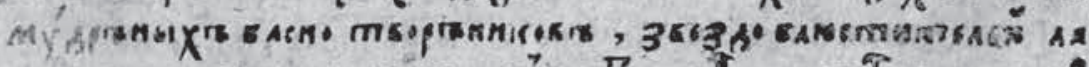

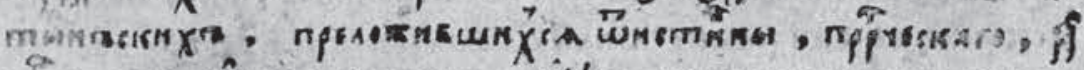

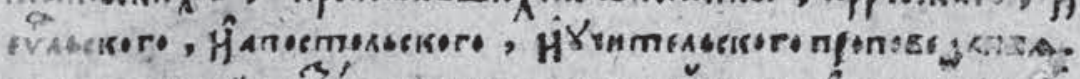

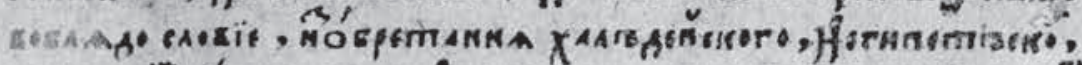

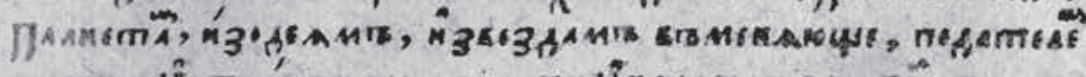

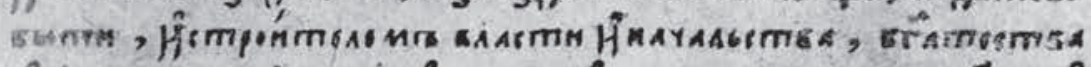

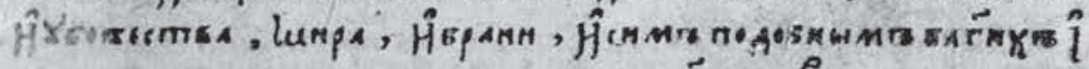

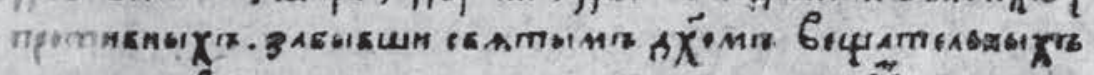

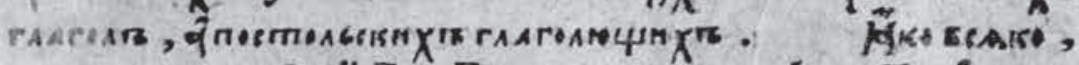

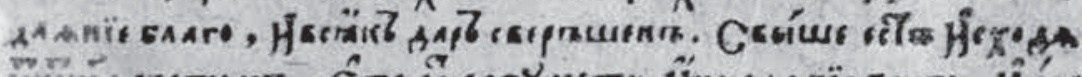

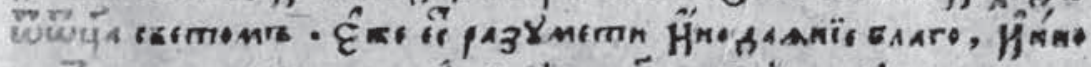

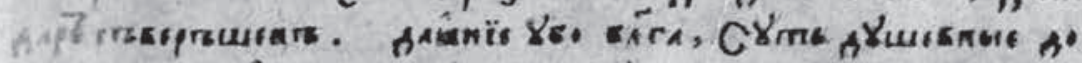

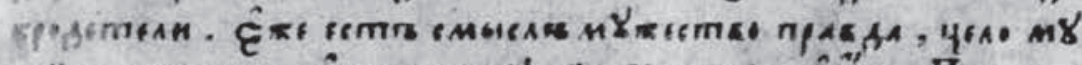

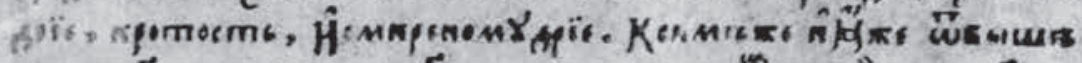

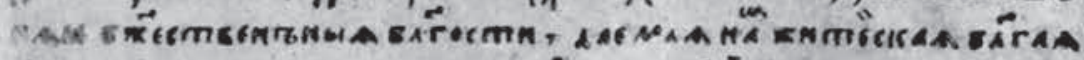

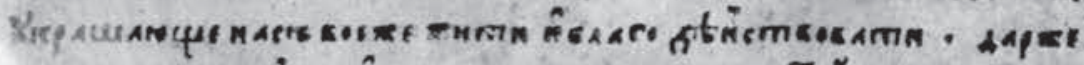

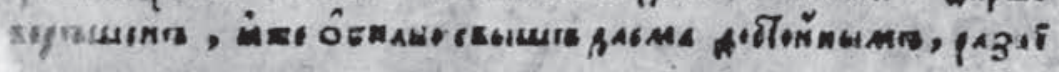
9end.

Іл. 1. Початок Послань патріарха Константинопольського Сремї II та патріарха Александрійського Сильвестра до князя Василя-Костянтина Острозького 


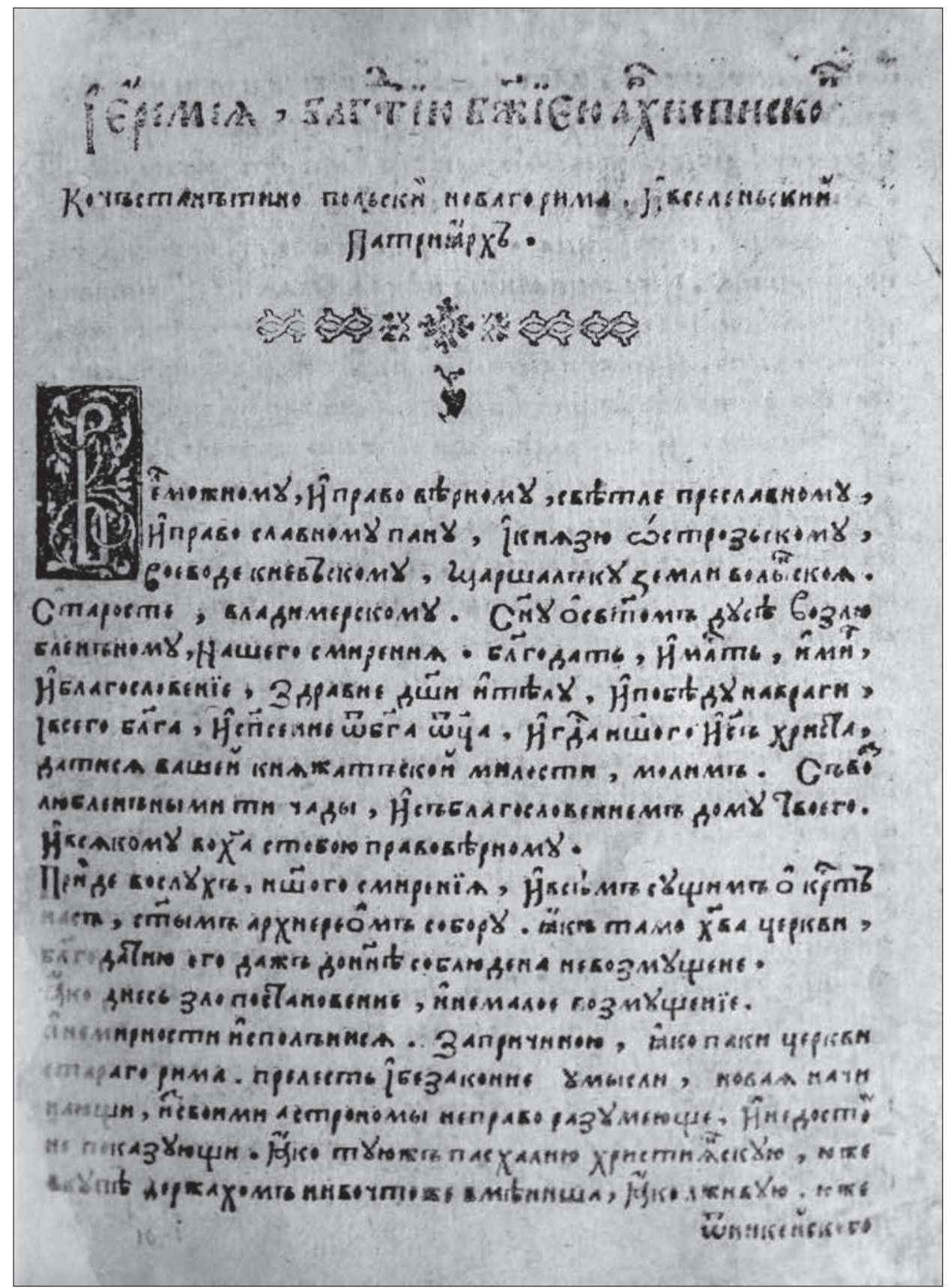

Іл. 2. Початок Послання патріарха Константинопольського Єремії II до руського народу 
Другу брошуру займає лише один текст, а саме послання Єремії, написане, очевидно, вже після завершення місії екзархів ${ }^{10}$. У ньому бачимо заклик дотримуватися традицій і «одгребатися» від латинських «блядословий и хулновещателных преданий» (с. 12).

Обидві згадані брошури ввів у науковий обіг митрополит Євгеній (Болховітінов), який у праці, опублікованій в 1825 р., не лише описав київський Софійський собор, а й навів історико-біографічні дані про осіб, що керували київською митрополичою кафедрою. У цій роботі автор розповідає про примірник «сей редкой книжки» в Києво-Печерській бібліотеці і без будь-яких доказів заявляє, що саме князь В.-К. Острозький усі перераховані послання «тогда же напечатал и издал из Острожской своей Типографии» ${ }^{11}$. Аби стало зрозуміло, що мав на увазі Євгеній (Болховітінов), пишучи про друкування послань «тогда же», звернімо увагу на інші видання, які він тут згадує. Серед опублікованих документів два були датовані, перший - послання до митрополита Онисифора - 11 січня 1583 р., другий - послання до єпископа Кирила Терлецького - 28 квітня того ж року.

Про причини, які змусили митрополита Євгенія прийти до наведеного висновку щодо місця і часу публікації послань патріарха Єремії II, можна лише здогадуватися. Ризикну припустити, що вирішальну роль тут зіграла наявність у складі однієї з брошур послання до князя В.-К. Острозького, а також розміщення в її кінці гравійованого герба того ж аристократа. Вірогідність нашого здогаду підтверджує випадок з першим у бібліографії описом одного з віленських братських видань, «Казания Кирилла Иерусалимского о антихристе и знакох его» Стефана Зизанія 1596 р., яке містило посвяту князю В.-К. Острозькому і було оздоблене його гравійованим гербом. Коли Василію Сопікову потрапив до рук екземпляр цієї книги без титульного аркуша, тобто лише із посвятою, він без будь-яких коливань пов'язав видання із острозькою типографією ${ }^{12}$.

Запропоновані митрополитом Євгенієм атрибуція і датування друкованих послань патріарха Єремії справили вплив на подальший спосіб їх описування в бібліографії. Переконання в тому, що друки побачили світ саме в Острозі, виявилося настільки стійким, що його не змогло похитнути навіть видане

${ }^{10}$ У цьому другому тексті послання до кн. В.-К. Острозького згадується як таке, що було відправлене раніше (с. 8).

${ }^{11}$ Евгений (Болховитинов). Описание Киевософийского собора и киевской иерархии, с присовокуплением разных граммат и выписок, объясняющих оное, также планов и фасадов константинопольской и киевской Софийской церкви и ярославова надгробия. - Киев, 1825. - С. 122, сноска 67.

${ }^{12}$ Сопиков В.С. Опыт российской библиографии, или Полный словарь сочинений и переводов, напечатанных на славенском и росийском языках от начала заведения типографий до 1813 года... - Санкт-Петербург, 1813. - Ч. 1. - № 571 (див. примітку до опису: «Экземпляр, с коего сие списано, заглавного листа не имеет. Оно <казанье> издано повелением Острожского Князя Константина Константиновича»). 
в 1838 р. повідомлення Дениса Зубрицького про існування пастирського послання патріарха «к русскому народу об устранении некоторых обычаев, несогласных с чистым христианским учением», опублікованого у Львові в $1591 \mathrm{p.} .^{13}$ (цей друк майже одразу був ототожнений із «острозьким» виданням). Поява цього повідомлення мала єдиний наслідок: в середовищі бібліографів правилом доброго тону стала вказівка на особливий погляд Д. Зубрицького ${ }^{14}$ 3 одночасною вказівкою у зведених каталогах «Грамоти Єремії», виданої у Львові в 1591 p. $^{15}$ I лише Іван Каратаєв спромігся зайнятися пошуком бодай якихось підстав для висновку про те, що видання послань вийшли в Острозі: в каталогах 1878 і 1883 pp. він писав, що послання надруковані «вероятно, в Остроге, потому что шрифт схож со шрифтом Острожской Библии». Датування видань в бібліографії не відзначалося різноманітністю: зазвичай, називали 1584 або близько 1584 р., рідше - 1583-1584 pp. і близько 1585 p.

Між тим підстав для сумніву щодо публікації згаданих послань в острозькій типографії у середині 1580 -х було чимало. I головна з них полягала навіть не у різкій зміні інтересів князя Василя-Костянтина, який $з$ невідомих причин то відновлював діяльність друкарні, то призупиняв ii, а в тому, кому вона власне належала. У той час навіть при фінансуванні книгодрукування впливовими особами типографія не потрапляла в їхню повну власність, певні права на неї залишалися за майстрами, що забезпечували й організовували сам процес роботи над виданнями. У цьому плані показовим був процес Мамоничів проти Петра Тимофійовича Мстиславця. За рішенням суду позивачі отримали лише те, що було виготовлене в друкарні, тобто книжки, тоді як типографічні матеріали, гравійовані прикраси і шрифти дісталися Мстиславцю16.

Схоже на те, що подібні взаємовідносини були в Івана Федорова з князем Острозьким. Принаймні, у списку майна померлого друкаря, укладеному 2 жовтня 1585 р., серед інших статків перелічені і типографічний станок, i деякі інструменти, і примірники Острозької Біблії (120 повних і 80 неповних). В документі зроблено особливий акцент на тому, що літер залишилося

${ }_{13}^{13}$ [Зубрицкий Д.И.]. О славянорусских типографиях в Галиции и Лодомирии // Журнал Министерства народного просвещения. - Санкт-Петербург, 1838. - Ч. 19, № 9. - С. 565.

${ }^{14}$ Сахаров И.П. Обозрение славяно-русской библиографии. - Санкт-Петербург, 1849. Т. 1, кн. 2: Хронологическая роспись славяно-русской библиографии: Издания, напечатанные кирилловскими и русскими буквами с 1491 до 1731 года. - № 73.

${ }^{15}$ Каратаев И.П. Хронологическая роспись славянских книг, напечатанных кирилловскими буквами. 1491-1730. - Санкт-Петербург, 1861. - № 88, 101; Ундольский В.М. Очерк славяно-русской библиографии. С дополнениями А.Ф. Бычкова и А. Викторова. - Москва, 1871. - № 95, 107; Каратаев И.П. Описание славяно-русских книг, напечатанных кирилловскими буквами. 1491-1730. - Санкт-Петербург, 1878. - Вып. 1: с 1491 по 1600 г. - № 96, 110; Каратаев И.П. Описание славяно-русских книг, напечатанных кирилловскими буквами. Санкт-Петербург, 1883. - Т. 1: с 1491 по 1652 г. - № 109, 124.

16 Зернова А.С. Первопечатник Петр Тимофеев Мстиславец // Книга: Исследования и материалы. - Москва, 1964. - Сб. 9. - С. 102-103. 
не більше, ніж на набір для одного відтиску на аркуші паперу, а тому їх навіть не стали оцінювати ${ }^{17}$. Здається, долю шрифтів Івана Федорова якоюсь мірою прояснює інший документ - вирок суду львівських єврейських старшин від 4 грудня 1584 р. про передачу у власність львівському міщанину Ізраїлю Якубовичу 140 книжок, надрукованих «руською мовою», а також матеріалу, літер, форм та інших друкарських приладів, які заставив йому 5 років тому Іван Федоров 3 сином Іваном за 411 польських злотих ${ }^{18}$. Втім, і це свідоцтво не дає відповіді на питання: хто і коли міг використати типографічні матеріали Івана Федорова для публікації послань патріарха Єремії, які, і справді, були надруковані шрифтами Острозької Біблії?

Немає сумніву в тому, що з'ясувати проблему могло лише послідовне, ретельне вивчення видань і видавничої практики епохи, але в підсумку успіх багато в чому визначив щасливий збіг обставин. Він полягав у тому, що відомому колекціонеру і бібліографу I. Каратаєву вдалося придбати за неймовірну ціну в 130 рублів двоаркушевий твір Максима Грека «Про хресне знамення» ${ }^{19}$, а також конволют 3 посланнями патріарха Єремії і так званої «Хіротонії» єпископа Луцького й Острозького Кирила Терлецького. Брошуру 3 твором Максима Грека (Іл. 3) І. Каратаєв миттєво зарахував до острозьких видань, випущених близько 1584 p. ${ }^{20}$ Очевидно, підставою для цього стало використання при іiі друці шрифта Острозької Біблії, за аналогією з уже відомими тоді посланнями патріарха Єремії. Розібратися з «Хіротонією» було складніше. Видання віддавна знаного в руській книжності «Повчання святительського новопоставленому єрею», яке набуло в Південно-Західній Русі значення Ставленої єрейської грамоти, що вплинуло і на його форму (воно видавалося у вигляді формуляра, з пробілами для внесення необхідних даних, див. Іл. 4) $)^{21}$, друкувалося не дрібним, острозьким, а середнім шрифтом (вимірювання 10 рядків дає 82 мм проти 50 в острозькому). Ця пам’ятка, приписана острозькій типографії завдяки факту виявлення у конволюті з посланнями Єремії, була датована 1587-1595 pp..$^{22}$, очевидно, з огляду на період

${ }^{17}$ Першодрукар Іван Федоров та його послідовники на Україні (XVI - перша половина XVII ст.): Збірник документів / Упоряд. Я.Д. Ісаєвич, О.А. Купчинський, О.Я. Мацюк, Е.Й. Ружицький. - Київ, 1975. - С. 78-80, № 47.

${ }_{18}$ Там само. - С. 69-70, № 38.

${ }^{19}$ Каратаев И.П. Описание славяно-русских книг, напечатанных кирилловскими буквами. 1491-1730. - Вып. 1. - № 97 (див. його примітку: «За эту брошюру в четыре страницы Каратаев заплатил 130 руб. В настоящее время заплатят больше»).

${ }^{20}$ Каратаев И.П. Хронологическая роспись славянских книг, напечатанных кирилловскими буквами. - № 89 («но, полагать должно, напеч. в Остроге, около 1584»)..

${ }^{21}$ Вознесенский А.В. Об одном издательском проекте патриарха Иосифа: Поучение святительское новопоставленному иерею 1649 года // Litterarum fructus: Сборник статей в честь С.И. Николаева. - Санкт-Петербург, 2012. - С. 43-45.

22 Бычков А.Ф. Дополнение к Очерку библиографии В. Ундольского, составленное, по экземплярам церковно-печатных изданий, находящихся в Императорской Публичной Библиотеке // Ундольский В.М. Очерк славяно-русской библиографии. - № 1. 


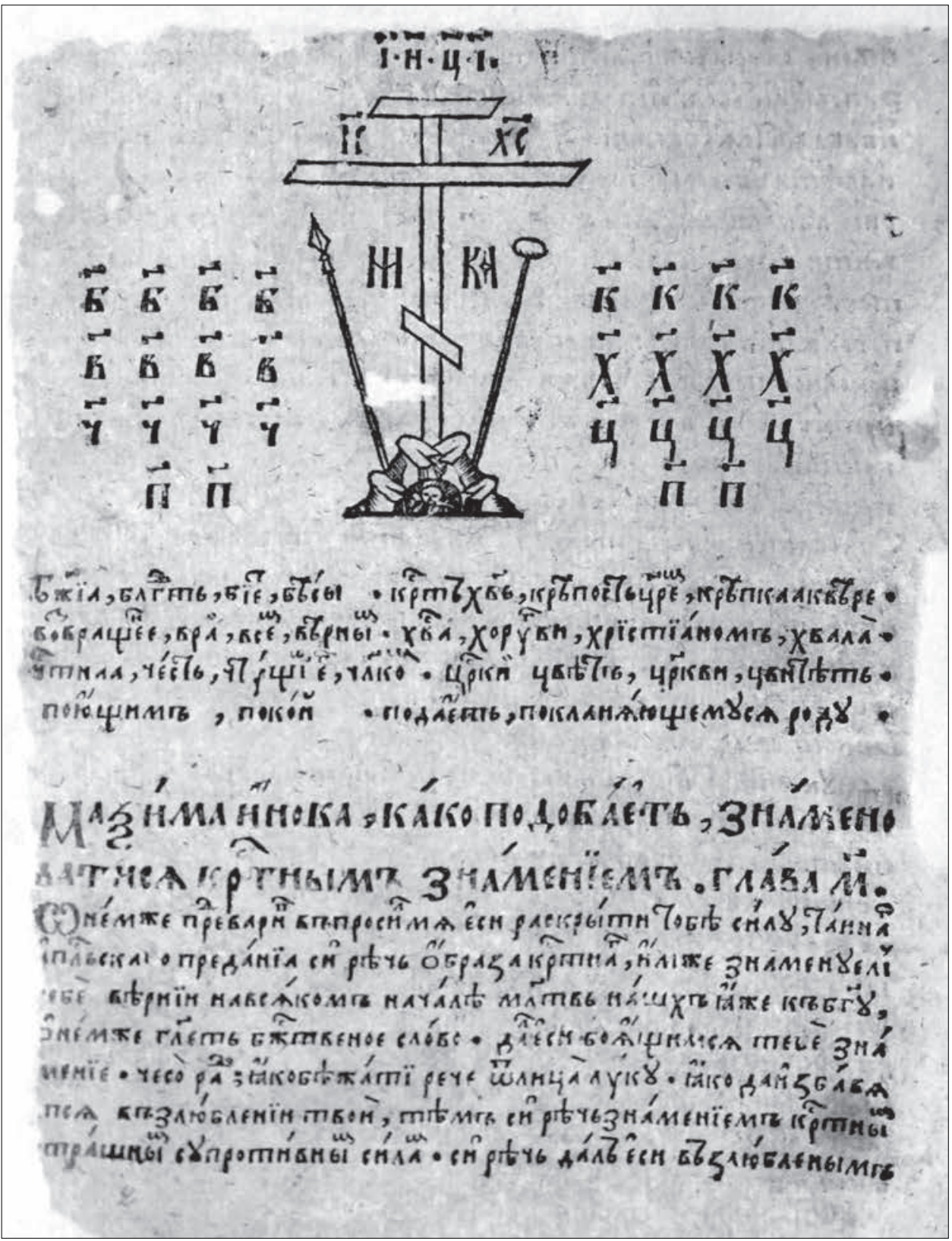

Іл. 3. Початок слова Максима Грека «Про хресне знамення» 


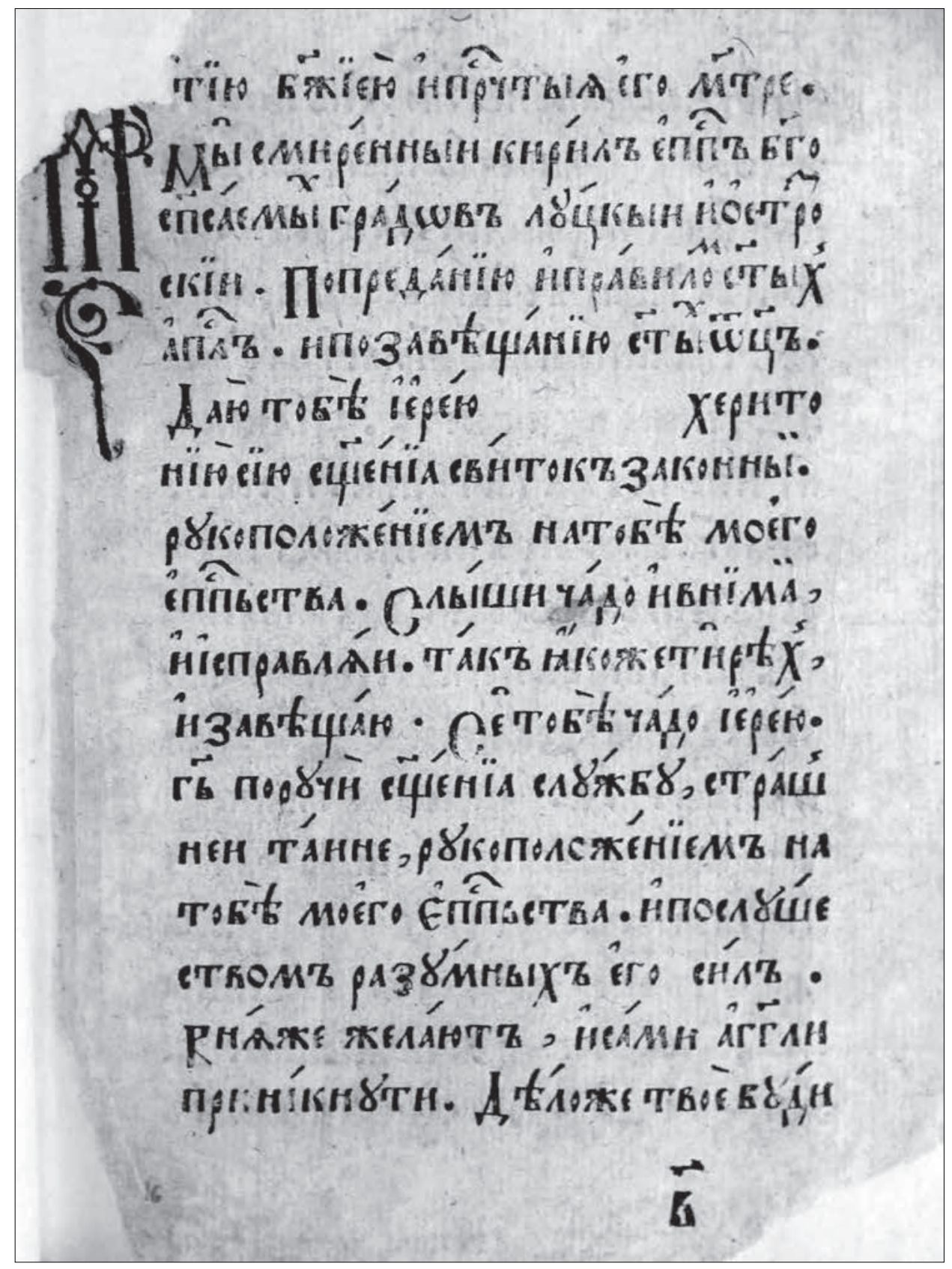

Іл. 4. Початок ставленої єрейської грамоти Кирила, єпископа Луцьького й Острозького 
перебування на Луцькій і Острозькій кафедрі єпископа Кирила Терлецького (носив відповідний сан у 1585-1595 рр.).

На те, що обидва видання були неслушно зараховані до острозьких, вказала Віра Лук’яненко. Створюючи каталог білоруських друків XVI-XVII ст., авторка виявила великий інтерес до особливостей орнаментного оздоблення книг і використання у них шрифтів. I хоча видання твору «Про хресне знамення» Максима Грека не ввійшло у 1-й випуск іiі каталогу ${ }^{23}$, воно з'явилося у додатку до 2-го випуску (Іл. 5). Це рішення обумовлювалося місцем друку у віленській типографії Мамоничів (про що свідчило використання в колофоні так званого курсивного, краще сказати - скорописного, шрифту), а сама публікація датована 1588 - початком 1590-х років (за станом цього шрифту $)^{24}$. Пізніше, в 1993 р., дослідниця запропонувала віднести до видань Мамоничів і Ставлену єрейську грамоту (висновок зроблений на підставі аналізу шрифту), хоч і залишила попереднє датування пам'ятки ${ }^{25}$. А от чіпати послання Сремії вона не наважилася, можливо, через виявлення в обох друках острозьких матеріалів: ініціалу і набірного орнаменту.

Підстави для переатрибуції двох видань у В. Лук'яненко були вельми серйозні, хай навіть вона й не врахувала всіх обставин, пов'язаних із використанням шрифтів у віленській типографії братів Мамоничів. Для останніх проблема шрифтів була однією з головних після невдалої спроби захопити типографію, майстром якої був Петро Мстиславець (1576 р.). Через це затягнулося відкриття власного видавничого центру Мамоничів. Перший його продукт, Служебник, побачив світ тільки у 1583 р., після того, як власники друкарні умовили Гриня Івановича (співробітника Івана Федорова) вирізати для неї два шрифти. Однак вибір виявився не дуже вдалим. Мамоничі отримали тільки крупний (як у Мстиславця) і дрібний (або півуставний, або скорописний) шрифти. Не бажаючи перевидавати нещодавно опубліковані Петром Мстиславцем книги, власники друкарні знайшли застосування для крупного шрифту тільки в Служебнику; інші книги, які можна було б запропонувати і для московського ринку, потребували середнього шрифту, а у Мамоничів його не було. Тому наступне видання (збірник творів патріарха Геннадія II Схоларія, Йоана Дамаскіна та Йоана Златоуста) побачило світ лише через два роки, в 1585-му. Схоже на те, що книга видавалася на замовлення і призначалася для поширення в межах Великого князівства Литовського, і саме тому Мамоничі змогли використати в ній наявні в них два дрібні шрифти. Наприкінці 1585-го - в 1586 році шрифтове господарство типографії оновилося, і в ньому з'явився середній шрифт. Звідки він узяв-

${ }^{23}$ Лукьяненко В.И. Каталог белорусских изданий кирилловского шрифта XVI-XVII вв. Ленинград, 1973. - Вып. 1: (1523-1600 гг.).

24 Лукьяненко В.И. Каталог белорусских изданий кирилловского шрифта XVI-XVII вв. Ленинград, 1975. - Вып. 2: (1601-1654 гг.). - С. 235.

${ }^{25}$ Лукьяненко В.И. Издания кириллической печати XV-XVI вв. (1491-1600). - № 95. 


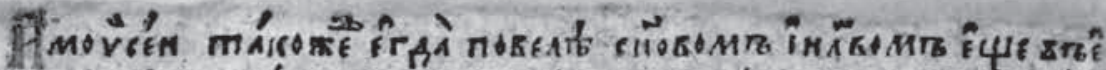
enrnits ố

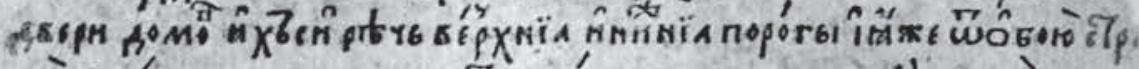

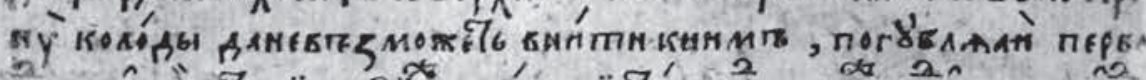

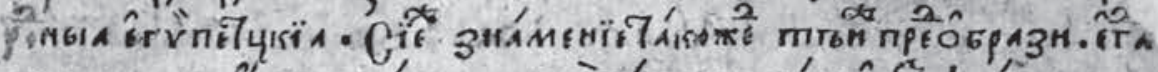

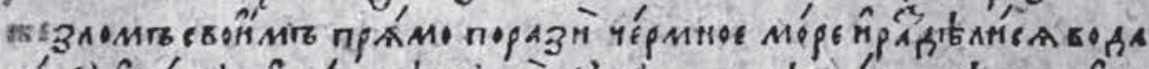

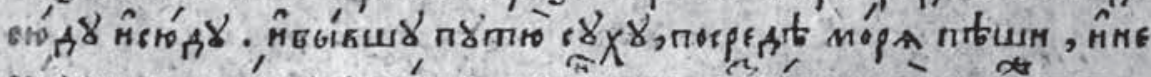

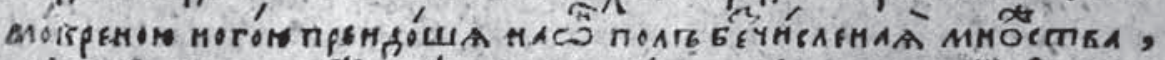

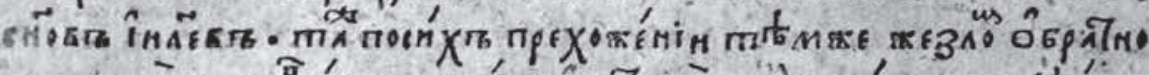

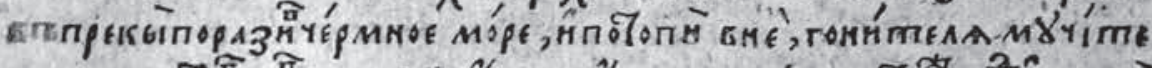

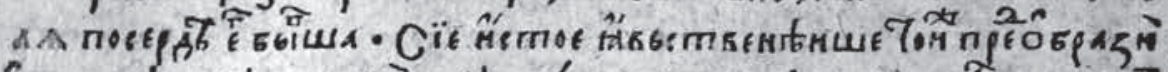

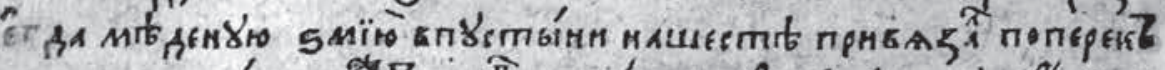
нанбте взнра́,

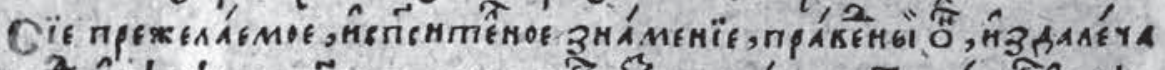

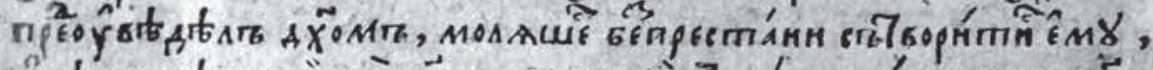

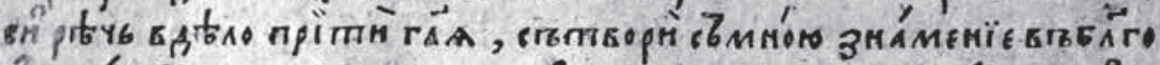

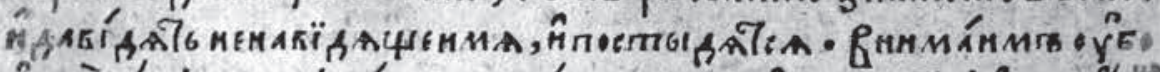

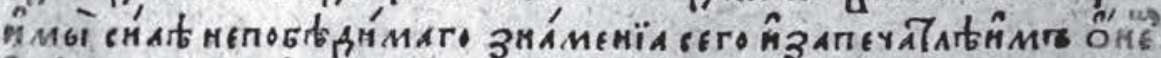

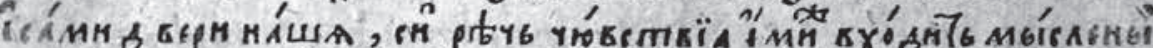

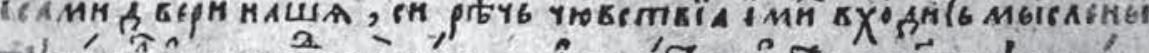

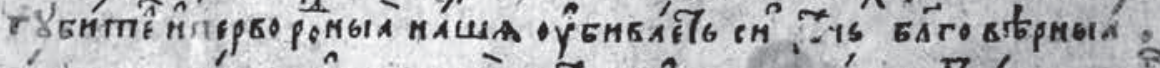

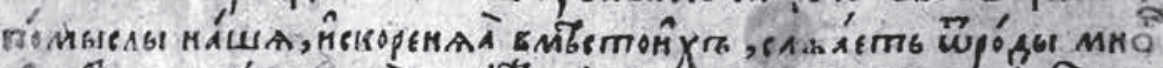

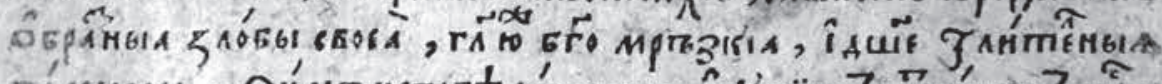
по́ммбІکА гона́

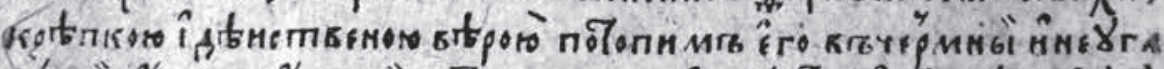

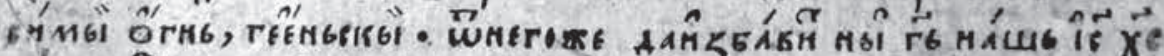
₹

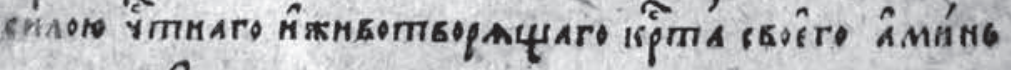

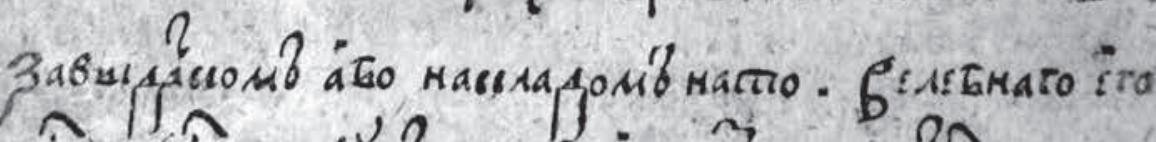

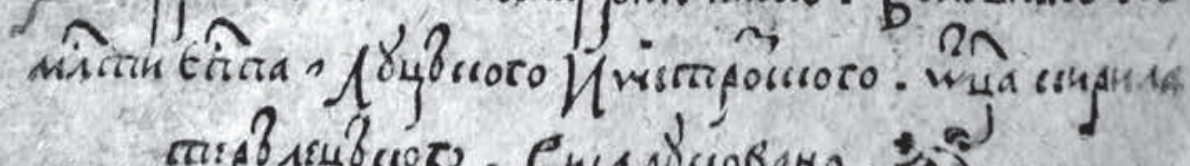

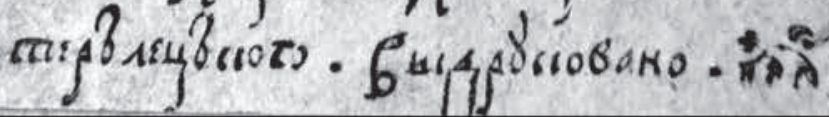

Іл. 5. Використання шрифту Острозької Біблї̈ й віленського скорописного шрифту наприкінці слова Максима Грека «Про хресне знамення» 
ся - невідомо, проте саме цей шрифт був використаний під час перевидання у 1586 р. заблудівського Псалтиря з Часлословцем. Як уже було згадано вище, він же фіксується у Ставленій єрейській грамоті. I, що важливо, цим же шрифтом надруковано Граматику слов'янської мови псевдо-Дамаскіна. Це видання заслуговує на особливу увагу, оскільки для набору колофону у ньому вперше використано шрифт Острозької Біблії (Іл. 6), який, відтак, до цього часу був придбаний Мамоничами.

Поза сумнівом, окрім шрифту Мамоничі придбали те, що залишилося від належного острозькій типографії оздоблення: деякі ініціали, кінцівки і набірний орнамент. «Острозький слід» можна побачити в таких віленських друках, як, наприклад, перше видання Статуту Великого князівства Литовського 1588 р. (набірний орнамент) або у Пандектах Нікона Чорногорця середини 1590-х (острозький ініціал). Послання патріарха Сремії II так само друкувалися у Вільні, на що вказує використання в одному з них власної орнаментики Мамоничів - невеликих гравійованих прикрас (Іл. 7), які, хоч і нагадують заблудівські, були вирізані спеціально для видання Псалтиря з Часословцем у 1586 р. Очевидно, що стан цих елементів оздоблення у посланнях Єремії гірший, ніж у щойно згаданому друці.

Послання патріарха Єремії навряд чи були видані в офіційній типографіï Мамоничів. Друкарня отримала цей спеціальний статус до 1586 p., i, відтак, випустила Трибунал 1581 р. (у 1586 р.), Статут Великого князівства Литовського 1588 р. (на зламі 1588 і 1589 рр., пізніше - ще два видання), Грамоту Сигізмунда III на проїзд патріарха Єремії 1589 р. У другій половині 1590-х тут же 3'явився ряд творів на захист Берестейської унії (примітно, що всі перераховані друки були набрані скорописним шрифтом). У зв'язку з цим можна припустити, що обидві брошури були опубліковані Мамоничами на замовлення.

У другій половині $1580-x$ років у віленській типографії, безперечно, на замовлення, надруковано два видання: твір «Про хресне знамення» Максима Грека, в колофоні якого прямо вказане ім'я замовника (Кирила Терлецького), і Ставлена єрейська грамота, яка була іменною - використовувати ії міг лише один, цілком конкретний архієрей - Кирило Терлецький. На те, що він звертався до послуг Мамоничів саме у 80 -х роках XVI ст., як видається, вказує наявність серед видань твору Максима Грека. Навряд чи Терлецький став би ініціатором публікації цього тексту в 90 -х роках, коли перейшов на сторону тих, хто займався підготовкою церковної унії.

Не виключено, що в 1580-х роках цей же владика виступив і замовником видання послань Єремії II. Напередодні поїздки патріарха до Речі Посполитої (візит відбувся у 1588-1589рр.) подібне діяння могло видатися єпископу, за чутками, чревоугоднику і перелюбнику, але чоловіку, небайдужому до кар'єрного росту, зовсім не зайвим. У будь-якому разі, в тому, як 


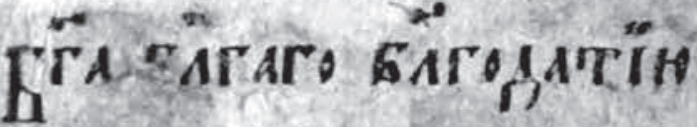

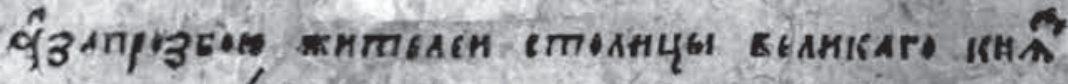

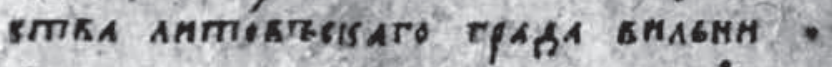

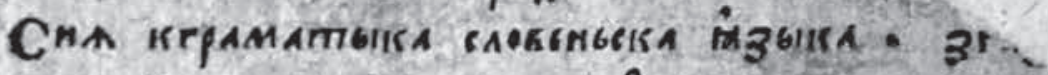

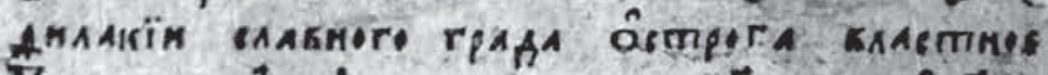

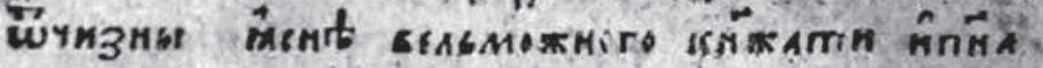

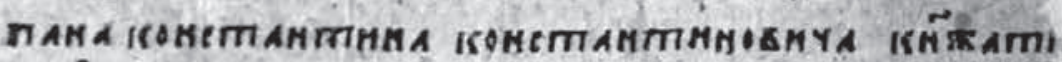

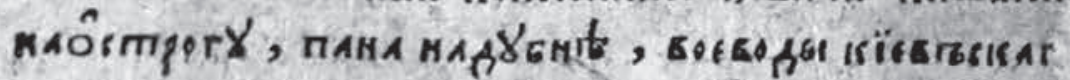

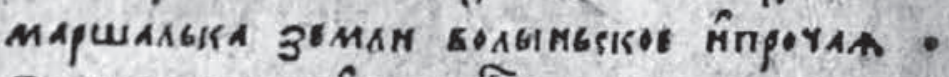

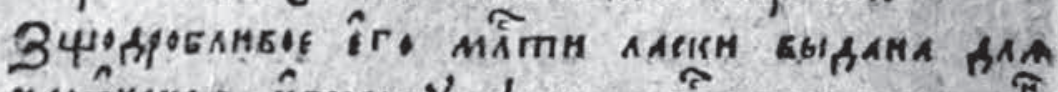

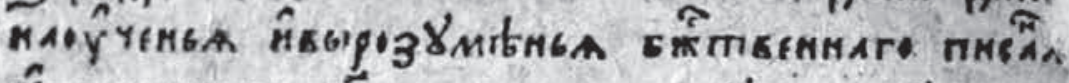

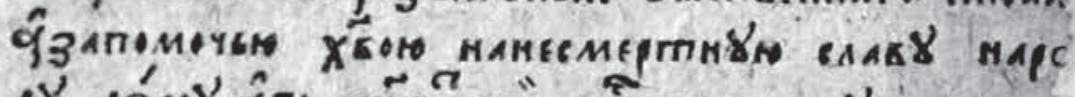

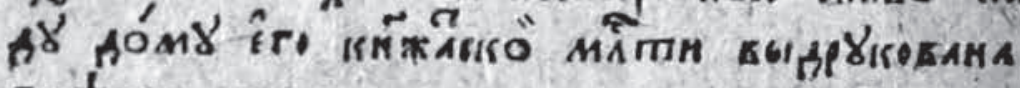

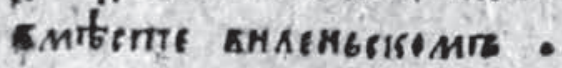

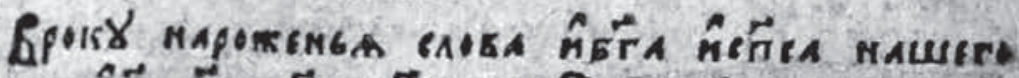

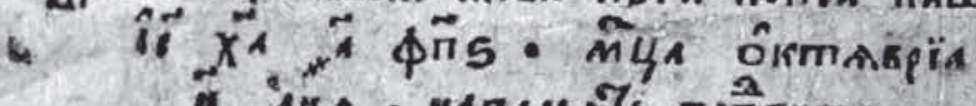

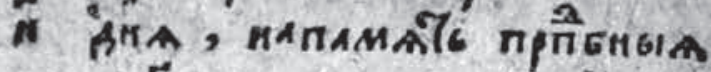
minge HaUEA neaArón ớWestrepenia estrma to 2 - 50 o $5 \%$ \%

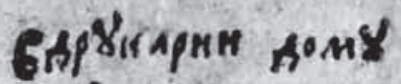

h.

TyAMOHHYOST

Іл. 6. Використання шрифту Острозької Біблї̈ в колофоні віленської Граматики слов'янської мови псевдо-Дамаскіна 


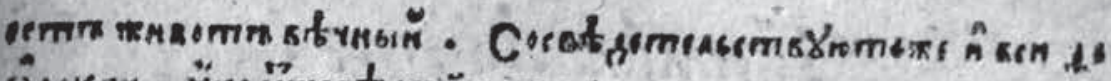

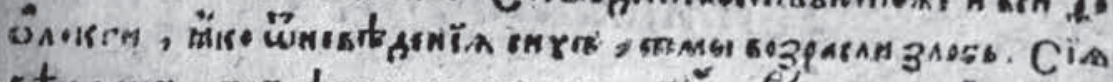

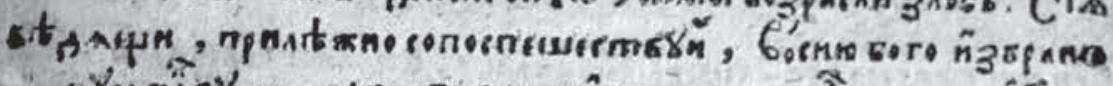

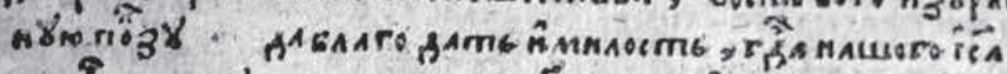

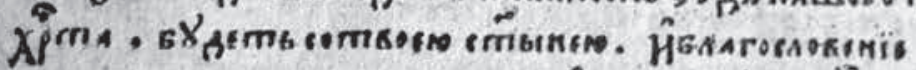

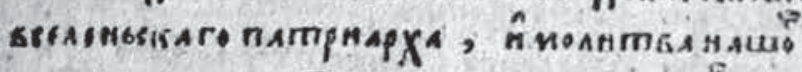

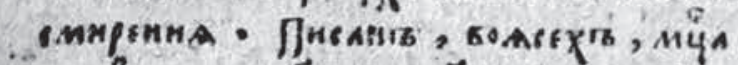

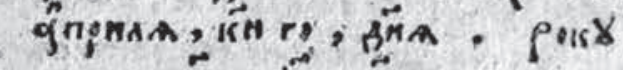

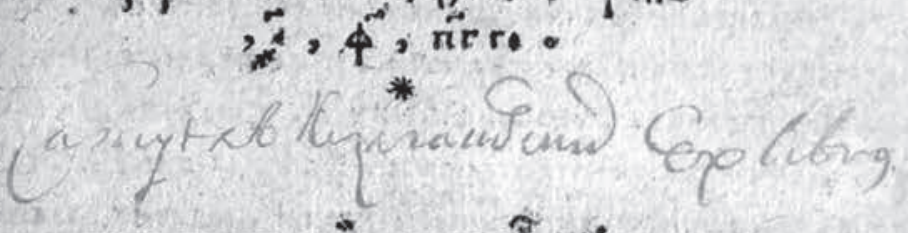

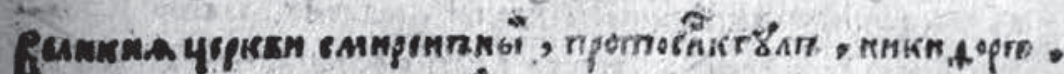
Hैesscap $X^{\text {rb }}$.

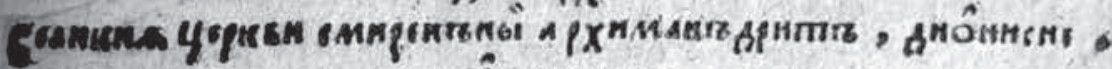
Hoiscaptro.

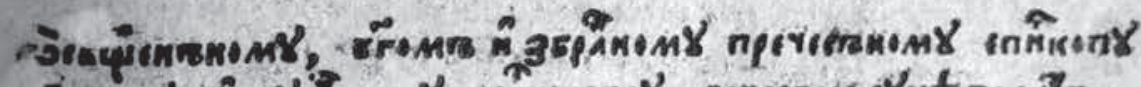

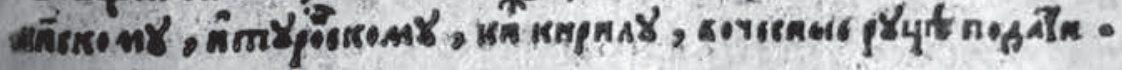

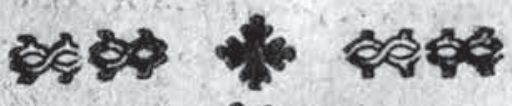

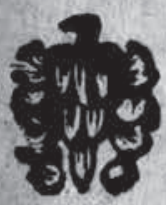

ร

Іл. 7. Використання орнаментики віленської типографії Мамоничів наприкіниі послань екзархів Никифора й Діонісія Кирилові Терлецькому 
друкувалися всі ці видання, можна побачити багато спільного: всі вони були маловитратними, набиралися найдрібнішим шрифтом і без кіноварі, тобто в один прокат.

Переатрибуція і передатування послань патріарха Єремії примушує критично поглянути на три інших видання, що вийшли в острозькій типографії поміж 1581 і 1594 рр.: «Ключ царства небесного» і «Календар римський новий» (1587), «Книжицю в шести розділах» (1588) і надруковану приблизно в той саме час Абетку.

Перша з цих книг, як випливає з її відтворення у зведеному каталозі видань другої половини XVI ст. ${ }^{26}$, була надрукована тим же шрифтом Острозької Біблії, яким були набрані перераховані віленські друки 1586-1590-х років. Її близькість за змістом із посланнями патріарха Єремії, а також наявність посвяти князю В.-К. Острозькому вказують на те, що вона побачила світ у Вільні, тобто мала таку саме, як і згадані видання, історію. Зарахування книги до продуктів острозької типографії грунтується на свідоцтві Йосефа Добровського, який у «Граматиці слов’янської мови» відзначив, що в Імператорській бібліотеці у Відні на власні очі бачив фрагмент книги тільки «Календар римський новий», в кінці якого була вказівка «написано у Академии Острозьской». Вірогідно, наводився і рік, а також, у зворотньому порядку, ім'я «Герасим Данилович Смотрицкий», й до нього дописка: «кто знает по арабски, тот легко поймет это» ${ }^{27}$. Ніхто, окрім Й. Добровського, цих записів не бачив, та навіть якщо вони існували, нескладно зрозуміти, що йшлося про час створення, а не типографічного втілення цього твору ${ }^{28}$.

Два інших видання - полемічна «Книжиця в шести розділах» і Абетка були випущені шрифтами, які отримали розповсюдження в Острозі в другій половині 1590-х років: дрібним (вимірювання 10 рядків дає 60 мм проти 50 мм шрифту Острозької Біблії) і середнім (вимірювання 10 рядків - 85 мм проти 82 мм віленського). Припускаємо, що в другій половині 1590-х вони i були надруковані, тим більше, що підставою для їх датування стали: для «Книжиці в шести розділах» - вказівка в кінці 5-го розділу: «написася сиа в лето от созданиа мира 7097. римляном же пишущым от по плоти рожства господня, 1588, по отщепенстве же их еже от нас в празникох лета 5» (арк. 66-й другого рахунку), для Абетки - знахідка в одному з їі примірників вплетеного аркуша, написаного рукою Томаса Хотрея, який навідувався до Росії в 1550-1560-х роках і помер у 1591 р., а також виявлення іншого іiі

${ }^{26}$ Гусева А.А. Издания кирилловского шрифта второй половины XVI века. - Рис. 104.1104.23.

27 Добровский Й. Грамматика языка славянского по древнему наречию, на коем россияне, сербы и другие славяне греческого исповедания, и далматы глаголиты римского исповедания имеют церковные книги / Пер. с лат. яз. М. Погодина. - Санкт-Петербург, 1833. - Ч. 1. - C. LX.

${ }^{28}$ Цієї ж думки щодо приписки дотримується й Ігор Мицько, див.: Мицько I.3. Острозька слов'яно-греко-латинська академія. - С. 43. 
примірника в конволюті з польською Абеткою, надрукованою в Кенігсберзі близько 1578 р. ${ }^{29}$ У будь-якому разі, те, що «Книжиця в шести розділах» 3’явилася у пізніший час, пояснює, чому «многогрешный и худший в христианех убогий василей» брав участь у підготовці острозьких видань настільки нерегулярно, з різницею в 10 років: один раз - близько 1588 р., інший - в $1598 \mathrm{p}$.

Обидва друки добре вписуються у ту видавничу програму, яка з’явилася після відновлення типографської діяльності в Острозі в середині 90-х років XVI ст. Вона була пов’ язана з різким несприйняттям князем В.-К. Острозьким церковної унії, етапи підготовки якої, очевидно, не були для нього секретом. Саме тоді друкарня стала випускати спочатку видання праць отців церкви, Йоана Златоуста і Василія Великого, потім - полемічні антиуніатські твори. Велика увага у видавничій програмі типографії стала приділятися також публікації навчальної і богослужебної літератури. Примітно, що для відновлення книгодрукування в Острозі типографам довелося придбати шрифт і орнаментальне оздоблення, що належали раніше Петру Мстиславцю і залишалися в його розпорядженні після судового процесу з Мамоничами.

Таким чином, у Ігоря Мицька були підстави стверджувати, що між 1581 і 1594 роками книгодрукування в Острозі зовсім припинилося. Усі видання, які за бібліографічними довідниками у цей час мали випускатися в Острозі, насправді побачили світ або пізніше, або в типографії Мамоничів у Вільні. Цей факт дозволяє зрозуміти причини виникнення особливо тісних зв'язків між острозькими книжниками і віленськими друкарями у 80-х роках XVI ст.: через відсутність типографії першим нічого не залишалося, як тільки звертатися за допомогою до других.

${ }^{29}$ Cyrillic Books printed before 1701 in British and Irish Collections: A Union Catalogue / Compiled by R. Cleminson, C. Thomas, D. Radoslavova, A. Voznesenskij. - London, 2000 . - № 38. 